\title{
Vitamin D status of healthy coastal fishermen of Bangladesh
}

\author{
Wasim Md Mohosin Ul Haque ${ }^{1}$, Md. Faruque Pathan ${ }^{2}$, MA Sayeed ${ }^{3}$ \\ ${ }^{1}$ Department of Nephrology, Bangladesh Institute of Research and Rehabilitation in Diabetes, Endocrine \\ and Metabolic Disorders, Dhaka, Bangladesh; ${ }^{2}$ Department of Endocrinology, Bangladesh Institute of \\ Research and Rehabilitation in Diabetes, Endocrine and Metabolic Disorders, Dhaka, Bangladesh; \\ ${ }^{3}$ Department of Community Medicine, Ibrahim Medical College, Dhaka, Bangladesh.
}

\begin{abstract}
Background and objectives: Vitamin D deficiency is now a global concern. Industrialization, urbanization and the decreasing participation in outdoor activities, with consequent sunlight deprivation, are thought to be the key factors in the increasing prevalence of vitamin $D$ deficiency among general population of many countries. It is presumed that healthy, adequately sun-exposed people should maintain adequate vitamin D levels. However, studies within this population are scarce. Hence, this study was conducted to find out the actual vitamin D status in healthy, adequately sun-exposed population living in coastal district of Bangladesh.
\end{abstract}

Material and Methods: One hundred and forty healthy fishermen living in costal district of Cox's Bazar ( $21^{\circ} 25^{\prime}$ North, $91^{\circ} 59^{\prime}$ East) of Bangladesh were enrolled in this study. Relevant data and blood samples were collected during August 2018, one of the months with lower zenith angle and higher UV index. Chemiluminescent micro-particle immunoassay (CMIA) was used to measure 25-hydroxy vitamin D3. Other relevant biochemical parameters measured were random blood glucose (RBG), serum creatinine, albumin, calcium, phosphate, alkaline phosphatase and intact parathyroid hormone (iPTH).

Results: Mean vitamin D level of the study population was $27.04 \pm 7.20 \mathrm{ng} / \mathrm{ml}$. Based on the cut off value of Endocrine Society, $70.7 \%$ of the study population had low vitamin D levels of which $26(18.6 \%)$ and $73(52.1 \%)$ were in vitamin D deficient $(<20 \mathrm{ng} / \mathrm{ml})$ and insufficient $(20-29.99$ $\mathrm{ng} / \mathrm{ml}$ ) categories respectively. Vitamin D level was normal in 41 (29.3\%) subjects. There was no significant difference in iPTH level between groups with low and normal vitamin D levels ( $p>.05$, $95 \% \mathrm{Cl}=-5.68226,1.21086)$.

Conclusion: The unexpectedly high prevalence of vitamin $D$ deficiency in this healthy and adequately sun-exposed population raises the question regarding the validity of the current cutoff value being used to assess the vitamin D status of Bangladeshi population. Future studies should be carried out to determine nation-specific, local cutoff values for vitamin D sufficiency.

IMC J Med Sci 2019; 13(2): 006. EPub date: 21 September 2019

\section{Introduction}

Human skin using sunlight produces vitamin D3, the cholecalciferol, which is further converted to 25 hydroxy vitamin D3 in the liver. This 25-hydroxy vitamin D3 is further converted in the kidneys to its active form 1, 25-dihydroxy vitamin D3 which is responsible for most of the biological effects of vitamin D [1]. We measure serum 25-hydroxy

Address for Correspondence:

Dr. Wasim Md Mohosin UI Haque, Associate Professor, Department of Nephrology, Bangladesh Institute of Research and Rehabilitation in Diabetes, Endocrine and Metabolic Disorders, 122 Kazi Nazrul Islam Avenue, Shahbag, Dhaka, Bangladesh; Email: wmmhaque@live.com 
vitamin D3 to assess vitamin D status. Vitamin D is not merely a vitamin but also a hormone [2], and participates in a diverse pool of physiological activities. Thus, its deficiency can lead to numerous diseases and disabilities. Significance of sun deprivation and consequent vitamin $D$ deficiency was first recognized in the early $17^{\text {th }}$ century during the industrial revolution and urbanization in Europe. The urbanization created congested cities, air pollution due to coal dust and led to the outbreak of vitamin D deficiency disorders called rickets in children [3]. In modern days, new elements of sun deprivation have been added. Children often prefer to remain indoors rather than going outside and most of the workers work within the building from dawn to dusk. This change in life style with less outdoor activity, less sunlight exposure, and consequently less production of ultraviolet-B (UVB)-induced vitamin D in the skin, ultimately ended with the pandemic of vitamin $D$ deficiency. About $50 \%$ of the people worldwide have vitamin $D$ insufficiency, and approximately 1 billion people suffer from vitamin $D$ deficiency [1].

The situation in Bangladesh is much worse. Several recent studies have reported that about $82 \%$ to $100 \%$ of the studied Bangladeshi population have low (insufficient or deficient) vitamin D levels [4-10]. In a study conducted within the working population, Mahmood et al found that $100 \%$ of the garments workers and $97 \%$ of agricultural/ construction workers had low vitamin D levels [5]. About $82 \%$ of postmenopausal women visiting general physicians had low vitamin D levels [6]. Surprisingly, $95 \%$ of the seemingly healthy population and $94.3 \%$ of Bangladeshi adult Muslim females had vitamin D levels lower than normal $[8,9]$. However, in these studies, health and sun exposure were not appropriately addressed. It is presumed that healthy individuals with adequate sun exposure should maintain optimal levels of vitamin D. However, study within this group of the population is scarce. Hence, this study was conducted to find out the actual vitamin D status in healthy, adequately sunexposed Bangladeshi populations.

\section{Materials and Methods}

Study population and sample collection: This was a cross-sectional study. A total of 140 healthy fishermen living in coastal district of Cox's Bazar $\left(21^{\circ} 25^{\prime}\right.$ North, $91^{0} 59^{\prime}$ East) were enrolled in the study. Cox's Bazar is a district of Bangladesh located about $306 \mathrm{~km}$ east of capital Dhaka city along the coast of Bay of Bengal. Fishermen who had at least 30 minutes of sun exposure between 11 am and 2 pm, three times a week for previous 6 months were enrolled. They were exposed to sunlight for an average of 6 to 8 hours spanning the recommended hours every day. The age range of the participants was between 19 to 65 years. Each participant was interviewed which included socio-demographic information, age, sex, family income, and education, as well as clinical history of present and past illness, medication. Individuals with chronic diseases, taking vitamin $D$, calcium or anti-epileptic drugs and those who refused to participate in the study were excluded. Anthropometric measures included height and weight and the body mass index (BMI) was calculated (weight in $\mathrm{kg} /$ height in meter ${ }^{2}$ ). Blood samples were collected aseptically after counseling and thorough clinical evaluation. Informed written consent was obtained from each participant prior to collection of blood sample. Specimens were preserved at $-60^{\circ} \mathrm{C}$ until analyzed

Biochemical tests: Chemiluminescent micro-particle immunoassay (CMIA) was used to estimate 25hydroxy vitamin $D$ to measure the serum vitamin $D$ level [11]. Vitamin D level was categorized into deficient, insufficient and adequate according to the Endocrine Society guideline [12]. Random blood glucose, serum creatinine, albumin, calcium, phosphate, alkaline phosphatase and iPTH were also estimated. Serum vitamin D level of our study population was compared with the reported vitamin D levels of other studies conducted previously on different Bangladeshi population.

IBM SPSS version 25 with python plug-in software was used to analyze the data.

\section{Results}

Mean age and body mass index (BMI) of the study population were $38.1 \pm 11.6$ years $(\mathrm{Cl}=35.3,39.3)$ and $22.4 \pm 3.2 \mathrm{~kg} / \mathrm{m}^{2} \quad(\mathrm{Cl}=22.2,23.7)$ respectively. Eight subjects were obese $\left(\mathrm{BMI} \geq 30 \mathrm{~kg} / \mathrm{m}^{2}\right)$ based on WHO criteria. Table - 1 shows the relevant biochemical parameters of the study population. The parameters 
Table-1: Biochemical parameters of the study population

\begin{tabular}{lcc}
\hline Parameters & Mean \pm SD & $95 \% \mathbf{C l}$ \\
\hline RBG (mmol/l) & $6.12 \pm 1.172$ & $5.92,6.31$ \\
S Creatinine (mg/dl) & $0.89 \pm 0.11$ & $0.88,0.91$ \\
S Albumin (g/L) & $45.34 \pm 2.84$ & $44.87,45.82$ \\
S Calcium (mg/dl) & $9.36 \pm 0.44$ & $9.29,9.44$ \\
S PO $_{4}(\mathrm{mg} / \mathrm{dl})$ & $3.30 \pm 0.57$ & $3.21,3.40$ \\
S Alk Phos (U/L) $^{82.06 \pm 21.36}$ & $78.49,85.64$ \\
S iPTH (pq/ml) & $21.19 \pm 9.40$ & $19.62,22.76$ \\
\hline
\end{tabular}

Note: $R B G=$ random blood glucose, $\mathrm{PO}_{4}=$ phosphate, Alk Phos=alkaline phosphatase, $i P T H=$ intact parathyroid hormone, $S=$ serum. were within normal range in all the participants except in 2 participants who had random blood glucose (RBG) more than $11.1 \mathrm{mmol} / \mathrm{L}$ and 7 had alkaline phosphatase levels higher than the upper normal limit. Mean serum vitamin $D$ level of the study population was $27.04 \pm 7.2 \mathrm{ng} / \mathrm{ml}$ (95\% $\mathrm{Cl}=25.84,28.25)$. Based on Endocrine Society guideline [12], 99 (70.70\%) participants had low vitamin D levels (Table-2). Mean vitamin D level of all our participants was significantly higher than the reported levels in other studies conducted previously on Bangladeshi population (Table-3). There was no significant difference in iPTH level, the surrogate marker of vitamin D deficiency, between groups with low and normal vitamin $D$ levels ( $p>.05,95 \% \mathrm{Cl}=-5.68226,1.21086$; Table-4).

Table-2: Serum vitamin D status of the study population based on Endocrine Society guideline [12]

\begin{tabular}{lcc}
\hline \multicolumn{1}{c}{ Status } & Number $(\%)$ & Vitamin D level $(\mathrm{ng} / \mathrm{ml})$ Mean \pm SD \\
\hline Deficient $(<20 \mathrm{ng} / \mathrm{ml})$ & $26(18.6)$ & $17.71 \pm 2.23$ \\
Insufficient $(20 \mathrm{ng} / \mathrm{ml}-29.9 \mathrm{ng} / \mathrm{ml})$ & $73(52.1)$ & $25.45 \pm 2.61$ \\
Adequate $(\geq 30 \mathrm{ng} / \mathrm{ml})$ & $41(29.3)$ & $35.79 \pm 5.07$ \\
All cases & $140(100)$ & $27.04 \pm 7.21$ \\
\hline
\end{tabular}

Table-3: Serum vitamin D levels of Bangladeshi population reported in previous studies compared to current study

\begin{tabular}{|c|c|c|c|}
\hline Author & $\begin{array}{c}\text { Type and number of study } \\
\text { population }\end{array}$ & $\begin{array}{c}\text { Vitamin D level ( } \mathrm{ng} / \mathrm{ml}) \\
\text { Mean } \pm \text { SD }\end{array}$ & p value \\
\hline Present study & Sun exposed healthy fishermen & $27.0407 \pm 7.21$ & - \\
\hline Islam et al., 2008 [4] & Female garments workers $(n=200)$ & $14.4 \pm 4.4$ & $<0.001$ \\
\hline \multirow[t]{2}{*}{ Mahmood et al.,2017 [5] } & Female garments workers $(n=40)$ & $14.2 \pm 2.6$ & $<0.001$ \\
\hline & $\begin{array}{l}\text { Female construction/agricultural } \\
\text { workers }(n=40)\end{array}$ & $22.4 \pm 2.4$ & $<0.001$ \\
\hline Ahmed et al., 2018 [6] & Postmenopausal women $(n=133)$ & $22.1 \pm 11.3$ & $<0.001$ \\
\hline \multirow[t]{2}{*}{ Hossain et al., 2018 [7] } & Males with body aches $(n=56)$ & $14.29 \pm 4.68$ & $<0.001$ \\
\hline & Females with body aches $(n=156)$ & $12.64 \pm 4.74$ & $<0.001$ \\
\hline Shefin et al., 2018 [9] & Adult Muslim females( $n=353)$ & $17.27 \pm 7.47$ & $<0.001$ \\
\hline Acherjya et al., 2019 [8] & Healthy population $(n=160)$ & $18.60 \pm 6.59$ & $<0.001$ \\
\hline
\end{tabular}

Table-4: Relevant serum biochemical markers related to vitamin D deficiency in population with low and normal vitamin $D$ levels

\begin{tabular}{|c|c|c|c|c|}
\hline \multirow{2}{*}{ Parameters } & \multicolumn{2}{|c|}{ Serum 25-hydroxy vitamin D (Mean \pm SD) } & \multirow{2}{*}{$p$ value } & \multirow{2}{*}{$\begin{array}{l}\text { 95\% Confidence Interval of } \\
\text { the Difference }\end{array}$} \\
\hline & low & normal & & \\
\hline Calcium (mg/dl) & $9.36 \pm 0.41$ & $9.36 \pm 0.52$ & $>.05$ & $-.17108, .15600$ \\
\hline $\mathrm{PO}_{4}(\mathrm{mg} / \mathrm{dl})$ & $3.38 \pm 0.54$ & $3.38 \pm 0.54$ & $>.05$ & $-.10408, .31556$ \\
\hline Alk Phos (U/L) & $82.80 \pm 19.63$ & $80.29 \pm 25.27$ & $>.05$ & $-10.36967,5.35908$ \\
\hline iPTH (pg/ml) & $21.85 \pm 9.69$ & $19.61 \pm 8.58$ & $>.05$ & $-5.68226,1.21086$ \\
\hline
\end{tabular}




\section{Discussion}

Higher mean vitamin D level $(27.04 \pm 7.21 \mathrm{ng} / \mathrm{ml})$ found among the fishermen living in coastal areas compared to levels reported in other categories of people by previous Bangladeshi studies signifies the importance of sun exposure to maintain adequate concentration of serum vitamin D. In a similar study, Lee et al found that healthy fishermen who lived in a coastal city in South Korea had 1.7 times higher mean serum concentration of $25(\mathrm{OH}) \mathrm{D}$ compared to the general occupation group $(23.74 \pm 8.88 \mathrm{ng} / \mathrm{mL}$ and $13.60 \pm 6.43, p<.001$ ) [13]. Despite having an abundant exposure to the sun, $71 \%$ of our study population had low vitamin D in terms of levels mentioned in the guideline of Endocrine Society. Similarly, the South Korean study reported low vitamin D levels in $78 \%$ of healthy coastal fishermen despite adequate sun exposure [13]. In India, 84.9\% of the healthy adult population of the coastal regions of Odisha had low vitamin D levels [14]. However, healthy individuals with reasonable sun exposure residing in an area between $35^{\circ} \mathrm{N}$ and $35^{\circ} \mathrm{S}$ should not have vitamin D deficiency, because this region has enough sun strength to maintain adequate vitamin D levels [15]. All the studies mentioned including the current one were carried out in highly sun exposed zone. It is an established fact that only 5 to 10 minutes of sun exposure can produce $3000 \mathrm{IU}$ of cholecalciferol that is sufficient to satisfy vitamin D requirement [16]. Study in India found that 30 minutes of sun exposure between 11 am and $2 \mathrm{pm}$, three times a week was enough to maintain adequate serum vitamin $D$ concentration [17]. So, this high prevalence of low serum $D$ in our study population is quite unexpected. Moreover, Vitamin D deficiency is usually associated with a raised $\mathrm{iPTH}$ level which is a surrogate marker of vitamin D deficiency. In our study, no significant difference was found between the serum iPTH levels of low and normal vitamin D groups.

High prevalence of low serum vitamin D levels in this healthy, adequately sun-exposed population, who were not expected to have vitamin $D$ deficiency by any means, raises the question about the validity of the current cutoff values described in different guidelines being used by us to determine the vitamin D status of our population. Future studies should be carried out to determine nationspecific, local cutoff values for vitamin D sufficiency.

\section{Acknowledgement}

We are thankful to Prof. J. Ashraful Haq, Department of Microbiology, Ibrahim Medical College for his help in editing the manuscript.

\section{Conflict of interest: None}

\section{References}

1. Nair R, Maseeh A. Vitamin D: the "sunshine" vitamin. J Pharmacol Pharmacother. 2012; 3(2): 118-126.

2. Reichrath J, Lehmann B, Carlberg C, Varani J, Zouboulis $\mathrm{CJH}$, Research M. Vitamins as hormones. Horm Metab Res. 2007; 39(02): 71-84.

3. Wacker M, Holick MF. Sunlight and Vitamin D: a global perspective for health. Dermatoendocrinol. 2013; 5(1): 51-108.

4. Islam MZ, Shamim AA, Kemi V, Nevanlinna A, Akhtaruzzaman $\mathrm{M}$, Laaksonen $\mathrm{M}$, et al. Vitamin $D$ deficiency and low bone status in adult female garment factory workers in Bangladesh. Br J Nutr. 2008; 99(6): 1322-1329.

5. Mahmood S, Rahman M, Biswas SK, Saqueeb SN, Zaman S, Manirujjaman M, et al. Vitamin D and parathyroid hormone status in female garment workers: a case-control study in Bangladesh. Biomed Res Int. 2017; 2017: 4105375.

6. Ahmed AS, Haque WMMU, Uddin KN, Abrar F, Afroz FA, Huque HF, et al. Vitamin D and bone mineral density status among postmenopausal Bangladeshi women. IMC J Med Sci. 2018; 12(2): 44-49.

7. Hossain HT, Islam QT, Khandaker MAK, Ahasan HAMN. Study of serum vitamin D level in different socio-demographic population-a pilot study. J Medicine. 2018; 19(1): 22-29.

8. Acherjya GK, Ali M, Tarafder K, Akhter N, Chowdhury MK, Islam DU, et al. Study of vitamin D deficiency among the apparently healthy population in Jashore, Bangladesh. Mymensingh Med J. 2019; 28(1): 214-221.

9. Shefin SM, Qureshi NK, Nessa A, Latif ZAJBMJ. Vitamin $D$ status among Bangladeshi adult 
muslim females having diabetes and using hijab. BIRDEM Med J. 2018; 8(3): 203-209.

10. Khan AU, Hossain MA, Rahman MA, Rahman $\mathrm{HW}$, Reza MA, Khan MK, et al. Estimation of vitamin $D$ levels among physicians working in a tertiary Level hospital of Bangladesh. Mymensingh Med J. 2019; 28(2): 322-327.

11. Hutchinson K, Healy $M$, Crowley V, Louw M, Rochev Y. Verification of Abbott 25-OH-vitamin D assay on the Architect system. Pract Lab Med. 2017; 7: 27-35.

12. Holick MF, Binkley NC, Bischoff-Ferrari HA, Gordon CM, Hanley DA, Heaney RP, et al. Evaluation, treatment, and prevention of vitamin D deficiency: an Endocrine Society clinical practice guideline. J Clin Endocrinol Metab. 2011; 96(7): 1911-1930.

13. Lee DH, Park KS, Cho MC. Laboratory confirmation of the effect of occupational sun exposure on serum 25-hydroxyvitamin D concentration. Medicine (Baltimore). 2018; 97(27): e11419.

14. Rattan R, Sahoo D, Mahapatra S. Prevalence of vitamin $D$ deficiency in adults in the coastal regions of Odisha, India. J Pharm Biol Sci. 2016; 11(6): 49-52.

15. Holick MF. Vitamin D: importance in the prevention of cancers, type 1 diabetes, heart disease, and osteoporosis. Am J Clin Nutr. 2004; 79(3): 362-371.

16. Holick MF. Vitamin D deficiency. N Engl J Med. 2007; 357(3): 266-281.

17. Harinarayan CV, Holick MF, Prasad UV, Vani PS, Himabindu G. Vitamin D status and sun exposure in India. Dermatoendocrinol. 2013; 5(1): 130-141. 